\title{
EVALUATION OF THE TEACHING BEHAVIOURS OF BIOLOGY TEACHERS IN SECONDARY SCHOOLS IN ORLU LGA, IMO STATE
}

\author{
Akachukwu Esther Ebele ${ }^{1}$, Onyebueke Anthony Chibuike ${ }^{2}$ and \\ Adimonyemma Ruffina Nkechi ${ }^{3}$ \\ ${ }^{1}$ Department of Science Education, Nnamdi Azikiwe University, Awka Anambra State. \\ ${ }^{2}$ Department of Biology Education, Federal College of Education (Technical) Umunze, \\ Anambra State. \\ ${ }^{3}$ Department of Biology, Nwafor Orizu college of Education Nsugbe, Anambra State.
}

\section{Cite this article:}

Akachukwu E.E., Onyebueke A.C., Adimonyemma R.N. (2021), Evaluation of the Teaching Behaviours of Biology Teachers in Secondary Schools in Orlu Lga, Imo State. British Journal of Education, Learning and Development Psychology 4(2), 1-7. DOI: 10.52589/BJELDPM7ICTGUZ.

\section{Manuscript History}

Received: 12 June 2021

Accepted: 9 July 2021

Published: 27 July 2021

Copyright $(92020$ The Author(s). This is an Open Access article distributed under the terms of Creative Commons AttributionNonCommercial-NoDerivatives 4.0 International (CC BY-NC-ND 4.0), which permits anyone to share, use, reproduce and redistribute in any medium, provided the original author and source are credited.
ABSTRACT: An evaluation of the teaching behaviours of biology teachers in secondary schools in Orlu LGA, Imo State was carried out using descriptive survey design. 194 respondents from SSS3 were used for the study. They were drawn from two boys' schools, one girls' school and one mixed school-94 male students and 100 female students. A five-point Likert questionnaire was used for data collection. The questionnaire consisted of 28 items drawn from the activities of teaching behaviours as regards the teachers' presentation of subject matter, class control and personality attributes. Data were analysed using mean scores, standard deviation and t-test statistics for hypothesis test. Results showed that biology teachers in Orlu Local Government Area performed to a very high extent in all the activities of teaching behaviours with respect to the concepts examined. Male and female students differed significantly $(p<0.05)$ in the mean response ratings of the teaching behaviours of biology teachers. Since biology teachers in Orlu Local Government Area performed satisfactorily to a very high extent in their teaching behaviours, it implies that they are very conversant with the biology curriculum being used in secondary schools and should be commended. It is recommended that there should be periodic seminars and workshops geared towards improving teachers' efficiency with respect to all the teaching behaviour concepts, so as to maintain good biology achievement amongst the students.

KEYWORDS: Teaching, Behaviour, Biology, Achievement, Concept, Teacher, Secondary. 


\section{INTRODUCTION}

At the senior secondary level, science is departmentalized into biology, chemistry, physics and geography. Biology, which is the study of different forms of life, their evolution, structures, functions, growth, distribution and taxonomy, occupies a unique position in the secondary school science curriculum. It serves as a prerequisite to the study of other lucrative and challenging professions like medicine, nursing, pharmacology, biochemistry and agriculture, among others. The vital role of the study of this subject in the economic, industrial and public life of the learners and the general humanity cannot be overemphasized (Ibe \& Ukpai, 2013; Akambi \& Kolawole, 2014).

Despite the values of the study of biology, the teaching and learning of the subject in secondary schools in Nigeria is not satisfactory. According to the Chief Examiner's report on biology in May/June 2000 (WAEC, 2000), the overall performance in the subject was fair. In the report, a number of weaknesses were noticeable among the candidates. They include disobedience of the rubrics, poor knowledge of the syllabus, inability to draw and label diagrams properly, inability to explain identified points and outright misinterpretation of some questions. The Chief Examiner's report of May/June 2009 (WAEC, 2009) was worse. There was an overall poor performance in the subject. All the Chief Examiner's report pointed accusing fingers to the ill-preparedness for the examination and poor coverage of syllabus. It was suggested that teaching should be effective to remedy candidates' weaknesses and that teachers should endeavour to emphasize relevant technical terms, give good notes and mark students' notes and assignments regularly.

However, the state of affairs in biology education teaching in secondary schools does not seem to represent effective teaching behaviour of the biology teacher since the most important and obvious of all determinants of good teaching is the achievement of the students. In fact, students' performance in both WAEC and NECO has since been abysmal (Obi \& Ewuzie, 2014). Analysis of performance rate in WAEC since 2008 showed that it was only in 2011 that $42 \%$ of candidates recorded credit passes in 5 subjects, with English and Mathematics. For other years, according to Obi and Ewuzie, the percentage pass rate hovered between 23 to 38 percent. The blame on the worrisome poor performances goes to all stakeholders including teachers. The teachers' lackadaisical attitude was noted. In the 2013/2014 Education for All Global Monitoring Report, the UNESCO Director General stated that an education system is only as good as its teachers and unlocking their potential is essential to enhancing the quality of learning (Obi \& Ewuzie, 2014).

Thus, it appears that the quality of the teachers and the teaching of biology have not been satisfactory (Ibeh \& Ukpai, 2003). The biology teachers may be using unsatisfactory methods and approaches, which instead of promoting student's achievement in learning outcomes and productivity rather hinder them. Hence, there is the necessity for assessing the teaching behavior of biology teachers if the achievement of set purposes will be made.

Furthermore, there is a growing interest in the assessment of teachers occasioned by best practices in the profession. Thus, interest is fostered by current needs for accountability and quality improvement in the teaching profession. There is also the need for assessment summative as a tool to ascertain whether teachers satisfy required standards, and formatively to formulate guidelines for professional development. 
Also, assessment of the teaching behaviour has always been done by outside or external supervisors from the post primary school service commission and ministry of education. The students themselves do not make an input. This research intends to fill the gap. There is also the obvious necessity to measure properly the skills required for task performance in economics teaching. This research therefore focuses on those teaching skills that are critical and which should be assessed for greater teaching efficiency and more excellent achievement of students especially in external examinations.

Some factors of teaching behaviours seem to have been hindering effective learning of biology which if not properly investigated, the impact of the aims of studying biology in secondary schools cannot be reasonably guaranteed. These factors include teacher presentation of subject matter, class control and personality attributes. The study sought to find out the extent of performance in teaching behaviours in each of the constructs as perceived by the biology students. It is hoped that the assessment of the teaching behaviours would help to find out what skills they need to improve upon for better efficiency. It will also provide bits and pieces of information on the competence requirements in training biology education teachers. This study therefore intends to improve teacher efficiency, increase achievement and attract more students to biology by assessing the teaching behaviours of biology teachers in secondary schools in Orlu Local Government Area of Imo State. Specifically, the study sought to answer the following research questions and hypothesis.

RQ1: What is the extent of achievement in teaching behaviours of biology teachers as regards the concepts presentation of subject matter, class control and personality attributes?

RQ2: What is the mean response rating of male students when compared with female students on the teaching behaviours of biology teachers as regards the presentation of subject matter (1$3)$ ?

HO1: There is no significant difference $(\mathrm{P}<0.05)$ between the mean response ratings of male and female students on the teaching behaviours of biology teachers as regards the presentation of subject matter (1-3).

\section{METHODOLOGY}

This study employed a descriptive survey research design. The study was carried out during a normal school term. Intact classes were used. The sample comprised 194 respondents made up of 94 males and 100 females sampled from a population of 883 biology students. The researchers employed purposive stratified random sampling technique to select the respondents from secondary schools in Orlu LGA of Imo State.

The instrument used for the data collection was a forced choice five-point likert type questionnaire, constructed from various items of teaching behaviours on the concepts: presentation of subject matter, class control and personality attributes. Each item of teachers' behaviour was scored on a maximum of 5 points: 5-outstanding, 4-very high extent, 3-high extent, 2-low extent and 1-none at all. The cumulative score of each student gives the score on the concept. 
The questionnaire was administered by the researchers and collected back immediately on completion to minimize loss. The data collected was subjected to descriptive statistics of mean and standard deviation while t-test statistic was employed to test the hypothesis.

\section{RESULTS}

Two research questions were answered in this study.

Research question one: What is the extent of achievement in teaching behaviours of the biology teachers as regards the concepts: presentation of subject matter, class control and personality attributes in Orlu LGA?

Table 1: Mean scores of the achievement of biology teachers on the concepts assessed.

\begin{tabular}{lllll}
\hline S/No. & Concept & Mean Score & $\begin{array}{l}\text { Standard } \\
\text { Deviation }\end{array}$ & Decision Rule \\
\hline $\mathbf{1}$ & Presentation of & 3.65 & 0.20 & VHE \\
& Subject Matter & 3.39 & 0.08 & HE \\
$\mathbf{3}$ & Class Control & 3.66 & 0.16 & VHE \\
& Personality Attributes & 3.56 & 0.16 & VHE \\
& Grand Mean & & & \\
\hline
\end{tabular}

where: HE = High extent

VHE $=$ Very high extent

Table 1 shows that the biology teachers in Orlu LGA had a very high extent of performance in all the activities of the teaching behaviours as regards the concepts assessed by students, with a mean score of 3.56 and standard deviation 0.16 . The biology teachers performed highest on personality attributes, with a mean response rating of 3.66 and standard deviation 0.16 , and then followed by presentation of subject matter, with a mean response rating of 3.65 and standard deviation 0.20 . In both personality attributes and presentation of subject matter, the biology teachers were adjudged to have had a very high extent performance rating.

Finally, the lowest response rating of the teaching behavior of biology teachers was on class control, with a mean response rating of 3.39 and standard deviation 0.08 . The performance on class control was to a high extent.

Research Question 2: What is the mean response rating of male students when compared with female students on the teaching behaviours of biology teachers as regards the concepts 1-3? 
Table 2: Mean response rating and standard deviation of the teaching behaviours of the biology teachers according to students' gender.

\begin{tabular}{|c|c|c|c|c|c|c|c|}
\hline $\begin{array}{l}\text { S/No } \\
\text {. }\end{array}$ & Concept & Male & SD & Decision & Female & SD & Decision \\
\hline 1 & $\begin{array}{l}\text { Presentation of } \\
\text { Subject Matter }\end{array}$ & 4.04 & 0.18 & VHE & 3.27 & 0.25 & $\mathrm{HE}$ \\
\hline 2 & Class Control & 4.10 & 0.19 & VHE & 3.17 & 0.12 & $\mathrm{HE}$ \\
\hline \multirow[t]{2}{*}{3} & Personality Attributes & 4.10 & 0.19 & VHE & 3.18 & 0.13 & $\mathrm{HE}$ \\
\hline & Grand Mean & 4.00 & 0.18 & VHE & 3.22 & 0.18 & $\mathrm{HE}$ \\
\hline
\end{tabular}

where: $\mathrm{HE}=$ High extent

VHE $=$ Very high extent

Table 2 shows that while male students' response rating shows that the biology teachers performed to a very high extent, the female students' response rating shows they performed at a high extent in all the activities of the teaching behaviours as regards the concepts 1-3. Thus, male and female students differed in the mean response ratings of the teachers' behaviour. The difference is in favour of male students who rated their biology teachers higher than the female students.

\section{Research Hypothesis}

HO1: There is no significant difference between the mean response ratings of male and female students on the teaching behaviours of biology teachers as regards the concept $1-3,(\mathrm{P}<0.05)$.

Table 3: Results of t-test calculation of the ratings of biology teachers' teaching behaviour as regards the concepts according to students' gender.

\begin{tabular}{|c|c|c|c|c|c|c|c|c|c|}
\hline S/No & Concept & $\begin{array}{l}\text { Male } \\
\text { Mean } \mathrm{X}_{1} \\
\end{array}$ & $\begin{array}{l}\text { Female } \\
\text { Mean } \mathrm{X}_{2} \\
\end{array}$ & $\mathbf{S D}_{1}$ & $\mathbf{S D}_{2}$ & df & T-cal & $\begin{array}{l}\text { T- } \\
\text { crit }\end{array}$ & Decision \\
\hline 1. & $\begin{array}{l}\text { Presentation } \\
\text { of } \\
\text { Subject } \\
\text { Matter }\end{array}$ & 4.04 & 3.27 & 0.18 & 0.27 & 192 & -24.76 & -1.96 & $\mathrm{~S}^{*}$ \\
\hline 2. & Class Control & 3.68 & 3.17 & 0.16 & 0.12 & 192 & -25.00 & -1.96 & $\mathrm{~S}^{*}$ \\
\hline 3. & $\begin{array}{l}\text { Personality } \\
\text { Attributes }\end{array}$ & 4.10 & 3.18 & 0.19 & 0.13 & 192 & -39.15 & -1.96 & $S^{*}$ \\
\hline & Grand Mean & 4.00 & 3.22 & 0.18 & 0.18 & 192 & -30.00 & -1.96 & $\mathrm{~S}^{*}$ \\
\hline
\end{tabular}

$\mathrm{df}=$ Degree of freedom, $\mathrm{SD}=$ Standard deviation

$\mathrm{S}^{*}=$ Significant at 0.05 probability level. 
The results in Table 3 show that the t-calculated value for the teachers' behaviour as regards concepts $1-3$ is greater than the $t$-critical value from the table at 0.05 level of significance. Since the calculated value of $\mathbf{t}$ is greater than the table value for $\mathbf{t}$, the hypothesis is rejected, which means that there is no significant difference between the mean response ratings of male and female students as regards the teachers' behaviour in biology. Therefore, the observed difference in the mean response ratings of the male and female biology students is real and cannot be attributed to chance. Thus, there is a significant difference $(\mathrm{P}<0.05)$ between the mean response ratings of male and female students in the teaching behaviours of biology teachers in Orlu Local Government Area of Imo State.

\section{DISCUSSION}

The study evaluated the teaching behaviours of biology teachers in secondary schools. Research question one aimed at finding out the extent of achievement of teaching behaviours of the biology teachers as regards the concepts: presentation of subject matter, class control and personality attributes. From the result of the analysis, the biology teachers' performance was to a very great extent in all the activities of the teaching behaviours.

The finding of the research is also in agreement with Anyanwu (2001), who found that religious education teachers performed to a high extent on all the activities in each of the six concepts studied, which includes lesson plan, teacher presentation of subject matter, evaluation, class control, personality attributes and religious characteristics. Furthermore, since all the students agreed that the biology teachers performed all the activities of teaching behaviours to a very high extent, what remains is for the students to reciprocate that by putting up a corresponding very high extent of achievement in their academic works and examinations.

More so, research question two aimed at finding out the mean response ratings of male students when compared with that of female students in the teaching behaviours. The result of the analysis showed that male and female students differed in the mean response ratings of the teaching behaviours of the biology teachers. The mean response rating of the female students was lower than that of the male students. The result is quite surprising because female students are by nature more emotional than the male ones and this difference should have accounted for the observed differences in the response ratings of the students.

The hypothesis tested sought to find out if there exists a significant difference $(\mathrm{P}<0.05)$ between the mean response ratings of male and female students in the teaching behaviours. From the analysis, the mean response ratings of male and female students on the teaching behaviours of the biology teachers differed significantly at 0.05 level of significance. However, the result differs from Anyanwu's finding which showed that male and female religious education teachers do not differ significantly with regard to each of the concepts studied.

\section{CONCLUSION}

From the findings and discussions, it could be observed that to the students, the biology teachers in Orlu Local Government Area of Imo State teach the subject satisfactorily. This implies that they are very conversant with the biology curriculum. Again, the significant 
difference in the mean response ratings of the male and female students shows that the students are examining the biology teachers' teaching behaviours from different perspectives. Furthermore, the significant difference in favour of male students shows that they are more positively disposed to their biology teachers and their teaching than their female counterparts.

\section{RECOMMENDATIONS}

The biology teachers should cultivate sustainable characteristics so as to continue to work judiciously in the teaching of the subject, for better achievement of the students in examinations. To sustain this trend also, stakeholders should ensure that only well trained and qualified biology teachers with high intellectual abilities are always recruited into the profession. Results of this type of students' assessment should be released to the teachers to help diagnose areas of strength and weaknesses for better achievements. Periodic seminars and workshops geared towards improving teaching efficiency in all the teaching behaviour concepts should be organized so as to sustain the good achievements.

\section{REFERENCES}

Akanbi, A. A \& Kolawole, C. B (2014). Effects of guided-Discovering and Self-Learning Strategies and Senior Secondary Students' Achievement in Biology Journal of Education and Leadership Development. 6(1), 19-42.

Anyanwu, F. N. (2001). Assessment of the Teaching Behaviour of Religious Education teachers in Enugu State Secondary Schools. Unpublished Ph.d Thesis. Nsukka University of Nigeria.

Ibe, V. S. O. \& Ukpai, P. O. (2003). The Role of Biology Education in Attaining the MDGs in Nigeria. In Okechukwu, A. (Ed), STAN 54th Annual Conference Proceedings ( $\mathrm{p}$ 222- 228).

Obi, I \& Ewuzie, K. (2014). Stakeholders decry perennial poor performance in WAEC Exams. Business Day Newspaper, Thursday, August 14, pages 1, 46 and 47.

West African Examination Council (2000). Chief Examiners' Report. Lagos: Animo Press. West African Examination Council (2009). Chief Examiners' Report. Lagos: Animo Press. 